\title{
Evaluation of the 2006-2008 Food Crisis on Household Welfare: The Case of the Sultanate of Oman
}

\author{
Houcine Boughanmi, ${ }^{1}$ Ahmed Al Shamakhi, ${ }^{2}$ Msafiri Mbaga, ${ }^{1}$ and Hemesiri Kotagama ${ }^{1}$ \\ ${ }^{1}$ Department of Natural Resource Economics, College of Agricultural and Marine Sciences, Sultan Qaboos University, \\ P.O. Box 34, 123 Muscat, Oman \\ ${ }^{2}$ Ministry of Commerce and Industry, P.O. Box 550, 100 Muscat, Oman \\ Correspondence should be addressed to Houcine Boughanmi; boughanh@squ.edu.om
}

Received 29 June 2013; Revised 4 December 2013; Accepted 19 December 2013; Published 16 February 2014

Academic Editor: Thomas S. Jayne

Copyright (C) 2014 Houcine Boughanmi et al. This is an open access article distributed under the Creative Commons Attribution License, which permits unrestricted use, distribution, and reproduction in any medium, provided the original work is properly cited.

The objective of this paper is to evaluate the impact of high food prices during the 2006-2008 food crisis period on the welfare of households in the Sultanate of Oman. The welfare impacts of price changes are estimated using the Hicksian compensating variation (CV) methodology. The compensating variation was estimated for 4 different income household groups as well as two location groups (urban-rural). Results suggest that all household groups suffered welfare losses due to the food crisis. On average, Omani households need to be compensated about $10.3 \%$ of their income for the price increase they experienced during the 2006-2008 period. Rural households are more affected than urban households with a required compensation of $12.4 \%$ and $9.87 \%$, respectively. In all cases most of the impact is felt on the first round where no consumption adjustment is made; the second round effect is comparatively small compared to the first-order effect. Total compensation required to compensate all households amounts to O.R. $266 \mathrm{M}$, that is, a $1.14 \%$ of GDP, whereas a compensation targeted to the low-income quartile amounts only to O.R. $26.7 \mathrm{M}$ representing $0.1 \%$ of GDP.

\section{Background}

The sharp increase in global food prices in recent years has raised serious concerns over the welfare and nutritional status of many people around the world. Unlike the previous episodes of price hikes, the recent food crisis (2006-2009) was long lived and has touched nearly all food commodities.

In a postcrisis reaction, countries have typically responded to the price surge by using a combination of trade and price policies designated to enhance the purchasing power of consumers. These policies ranged from tariff elimination and exports bans to universal food subsidies, price fixing, and other food and income safety nets [1]. Whilst these policies have helped to attenuate somehow the negative effects of the food price surge on low-income households, they are in most cases nontargeted and therefore not cost effective [2]. Universal food subsidies and price controls in particular are associated with unsustainable budgetary costs, distortion in trade, and production and development of black markets. In addition their benefits are highly biased toward high income consumers and therefore not equitable $[3,4]$. The design and implementation of targeted policies, however, are quite demanding in terms of information related to food consumption patterns and household behavior in the face of price movements. In addition, information on the effects of price changes and the channels through which these effects are occurring are important to know in order to design the appropriate policy responses.

The objective of this paper is to evaluate the impact of high food prices on household welfare in Oman during the 2006-2008 food crisis period. The impact evaluation is useful to provide the behavioral information required to design targeted response policies to high price, such as cash transfers. Because of its high dependence on food imports, Oman has experienced one of the highest domestic food inflation rates in the Middle East during the food crises 
period that has heavily impacted low-income consumers. In response to the price increase, Oman has fixed the price of all rice brands, sugar, and wheat that are available through the Public Authority for Stores and Food Reserves [5] ${ }^{1}$. In addition the Public Authority for Stores and Food Reserves (PASFR) has increased its strategic food stocks to cover an extended period of national consumption (2 years for rice and 1 year for sugar) and invested in the operation of new sale outlets. The increasing role that the PSAR is expected to play in stabilizing food prices and insuring food security will put a heavy pressure on the government budgetary cost in the face of continuous increases in global food prices. The design of new schemes of food distribution and subsidies that are targeted to those who are more affected by the price surge (i.e., direct monetary transfers, food stamps, or other forms of compensation) would help in insuring the sustainability of the PASFR food distribution system.

The household welfare impact of price changes will be evaluated using the Hicksian compensating variation (CV) methodology. The compensating variation measures the changes in money income or expenditure required to maintain a constant utility after the change in prices. In a policy context, it represents the money transfer required to compensate households for the inflationary pressure that occurred during a particular period of time.

Section 2 of the paper will present the methodology used to estimate the compensating variation and discuss the data issues, Section 3 will overview the household expenditure and income survey, Section 4 will describe the household consumption pattern in Oman, Section 5 will present and discuss the results, and Section 6 will conclude.

\section{Methods}

The welfare impact of food price changes on households can be measured in monetary terms by the concept of compensating variation $(\mathrm{CV})$ introduced by Hicks and developed by Deaton and Muellbauer [6]. It has then been used and applied in many empirical studies including more recently Ackah and Appleton [7], Ivanic and Martin [8], and Dessus et al. [9]. The compensating variation measures the changes in money income or expenditure $c(\cdot)$ required to maintain a constant utility (the initial level of utility) after the change in prices; that is,

$$
\mathrm{CV}=C\left(u^{0}, p^{1}\right)-C\left(u^{0}, p^{0}\right)
$$

where $p^{1}$ and $p^{0}$ represent a vector of prices after the food crisis and before the food crisis and $u^{0}$ is the household utility before the food crisis. The expenditure function $c(\cdot)$ represents the minimum expenditure required by the household to achieve a specific level of utility $u$ at price level $p$. In a policy context, the $\mathrm{CV}$ represents the money transfer required to compensate households for the inflationary pressure that occurred during a given period. It provides a measurement on how well or worse off the consumers are in response to the changes in prices during a specified period of time.
The CV can be approximated by a second-order Taylor expansion of the minimum expenditure function as [10]

$$
\Delta \ln (c)=\sum_{i} w_{i} \ln p_{i}+\frac{1}{2} \sum_{i=1} \sum_{j=1} w_{i} \varepsilon_{i j}^{*} \Delta \ln p_{i} \Delta \ln p_{j}
$$

where $w_{i}$ is the budget share of commodity $i$ before the food crisis $\Delta \ln p_{i}$ approximates the proportional change in the price of commodity $i$ and $\varepsilon_{i j}^{*}$ is the compensated price elasticity of commodity $i$ with respect to the price change of good $j$. The first part in (2) represents the first round effect of the price change, that is, the effect on welfare before the household makes any adjustments in response to the price change, therefore disregarding substitution effects in consumption. The second term represents the second round effects, where the household had enough time to make substitution adjustments to the price change [7].

The compensated price elasticities (Hicksian elasticities) $\varepsilon_{i j}^{*}$ are derived using the following formula [11]:

$$
\varepsilon_{i j}^{*}=\varepsilon_{i j}+\eta_{i} w_{j}
$$

where $\varepsilon_{i j}$ is the uncompensated price elasticity (Marshallian elasticities), $\eta_{i}$ is the expenditure elasticity, and $w_{i}$ is the budget share of the various commodities included in the study.

The information needed to estimate the welfare effects (2) requires the knowledge of (a) the budget shares, (b) the magnitude of the price changes during the food crises period, and (c) the expenditure and price elasticities. Budget shares for individual commodities are obtained from the Household Expenditure and Income Survey (HEIS) conducted by the Omani Ministry of National Economy during the period 2007-2008. Expenditure elasticities for 4 different income groups are obtained using the HEIS data and estimating a system of Engle share equations augmented with household characteristics $^{2}$ (Table 1). The HEIS covers 8 regions of the Sultanate of Oman and has records on food and nonfood expenditure of 6800 households (Omani and expatriate) along with their demographic and income characteristics ${ }^{3}$.

Estimating price elasticities from household surveys is however problematic because of the lack of price variability in the data (cross sectional data). Deaton [12] developed a method that yields consistent price elasticities using information on unit values and quantities. However the information on quantities consumed at the household level is missing from the Omani HEIS survey. Therefore and because of this limitation, estimates of price elasticities are obtained from the literature [13-15] (Table 2).

The last ingredient to estimate (2) is the price variation during the food crisis period. We used the change in the consumer price index (CPI) for various commodities from 2006 to 2008 to reflect this variation (Table 3). As Oman is an open economy with little trade barriers, the change in the CPI reflects the change in the global commodity prices. 
TABLE 1: Estimated expenditure elasticities for the whole sample and by income groups.

\begin{tabular}{|c|c|c|c|c|c|}
\hline $\begin{array}{l}\text { Commodity } \\
\text { food groups }\end{array}$ & $\begin{array}{c}\text { Whole sample } \\
\quad N=6789\end{array}$ & $\begin{array}{r}\text { 1st quartile } \\
N=1701\end{array}$ & $\begin{array}{c}\text { 2nd quartile } \\
\quad N=1697\end{array}$ & $\begin{array}{c}\text { 3rd quartile } \\
\quad N=1705\end{array}$ & $\begin{array}{c}4 \text { th quartile } \\
N=1717\end{array}$ \\
\hline Cereals & 0.883 & 1.100 & 1.024 & 0.954 & 0.797 \\
\hline Meat & 1.438 & 1.160 & 0.923 & 1.200 & 1.552 \\
\hline Fish & 0.920 & 1.129 & 1.016 & 0.876 & 0.814 \\
\hline Dairy & 0.859 & 1.150 & 1.324 & 1.342 & 0.847 \\
\hline Oil and fat & 0.973 & 1.060 & 1.118 & 1.133 & 0.922 \\
\hline Fruits and veg. & 0.955 & 1.870 & 1.070 & 0.980 & 0.790 \\
\hline Sugar & 1.176 & 1.00 & 0.980 & 0.927 & 1.217 \\
\hline Beverage & 0.691 & 0.840 & 0.932 & 0.908 & 0.876 \\
\hline Others & 0.933 & 0.772 & 0.735 & 0.735 & 0.760 \\
\hline
\end{tabular}

Source: own derivation from Engel share equations.

TABLE 2: Hicksian own and cross price elasticities.

\begin{tabular}{lcccccccccc}
\hline & Cereals & Meat & Fish & Dairy & Oil and fat & Fr. and veg. & Sugar & Bev. & Others \\
\hline Cereals & $-\mathbf{0 . 1 2 3}$ & 0.075 & -0.113 & -0.038 & 0.000 & 0.327 & -0.025 & -0.143 & -0.005 \\
Meat & -0.185 & $-\mathbf{0 . 1 8 5}$ & 0.703 & 0.130 & 0.296 & 0.426 & 0.078 & 0.063 & -0.341 \\
Fish & -0.038 & 0.213 & $-\mathbf{0 . 4 2 4}$ & 0.076 & 0.059 & -0.366 & 0.057 & -0.010 & 0.434 \\
Dairy & -0.084 & 0.333 & 0.057 & $-\mathbf{0 . 3 7 8}$ & -0.002 & -0.172 & 0.084 & 0.026 & 0.001 \\
Oil & -0.170 & 0.290 & 0.193 & 0.241 & $-\mathbf{0 . 2 3 7}$ & 0.193 & -0.001 & -0.007 & -0.502 \\
Fr. and veg. & 0.177 & -0.250 & -0.128 & -0.681 & 0.010 & $-\mathbf{0 . 1 7 6}$ & 0.058 & 0.052 & 0.937 \\
Sugar & -0.785 & 0.283 & 0.166 & 0.442 & -0.065 & 0.249 & $-\mathbf{0 . 1 2 8}$ & 0.116 & -0.279 \\
Beverage & -0.025 & 0.080 & -0.154 & -0.078 & -0.016 & 0.113 & 0.048 & $-\mathbf{0 . 5 0 2}$ & 0.725 \\
Others & 0.002 & 0.203 & -0.263 & 0.127 & -0.020 & 0.116 & 0.087 & 0.082 & $-\mathbf{0 . 3 3 3}$ \\
\hline
\end{tabular}

Source: calculation from expenditure elasticities in Table 4 and uncompensated price elasticities from the literature.

The bold diagonal numbers are own price elasticities.

\section{Overview of the Household Expenditure Survey in Oman}

The main purpose of the national household expenditure survey was to evaluate the consumption and the welfare (standard of living) of the country population. Welfare measurements include income or total expenditure and consumption of food and nonfood items. The methodology used in conducting the survey was based on the UN National Household Survey programs as well as the World Bank's living standard measurement survey programs. In Oman, the Ministry of National Economy carried out the first survey in May 1999, which continued for one year. The second survey was conducted in 2006-2007 and then in 2007-2008. According to the Ministry of National Economy, the reasons for conducting the survey annually is to provide a more realistic data, less affected by the yearly fluctuation, and to monitor the change that might occur due to external shocks, such as oil prices.

The sampling methodology is basically to use a random sample representing the community within the Sultanate, drawn from the latest population census. The sample consists of 12 partial representative samples, one in each month. Each household was requested to record consumption and expenditure during a whole month. The survey consists of
Nationals and expatriate living in all governorates and regions of the Sultanate.

In the latest survey, 250 counting areas of the total counting areas in the sultanate have been selected, representing 4759 households of which 3190 are Omanis and 1469 nonOmanis. As such, the survey was considered as representative of all months and all households in the Sultanate of Oman [16].

In this paper, the 1999-2000 survey data is used to estimate the budget shares equations and determine income elasticties ${ }^{4}$. However, price changes as well estimates of commodity budgets shares of the 2008 household surveys are used in estimating welfare effects of the 2007-2008 food crisis.

\section{Household Food Consumption Patterns in Oman}

Table 4 shows food consumption in the sultanate of Oman in 2007-2008, highlighting the main changes in comparison with that of the 1999-2000 household survey. As shown, food consumption in 2007-2008 represents around $28.8 \%$ of the total household expenditure compared to $30.3 \%$ in 1999 2000. This decrease in the proportion of food expenditure is in conformity with Engel Law which stipulates that as 
TABLE 3: CPI for food products in the Sultanate during 2006-2008 (base year 2000).

\begin{tabular}{lcccc}
\hline & 2006 & 2007 & 2008 & \% Change 06-08 \\
\hline Cereals products & 105.40 & 119.10 & 169.40 & 60.72 \\
Meat and poultry & 115.70 & 137.20 & 166.00 & 43.47 \\
Fish & 119.70 & 132.70 & 165.00 & 37.84 \\
Dairy and eggs & 104.98 & 113.50 & 144.36 & 37.51 \\
Oil and fats & 104.00 & 113.50 & 182.10 & 75.10 \\
Fruits and veg. & 126.80 & 139.77 & 157.51 & 24.22 \\
Sugar products & 118.40 & 122.70 & 137.10 & 15.79 \\
Beverage nonalcoholic & 100.00 & 100.60 & 101.80 & 1.80 \\
Others & 101.21 & 108.76 & 126.37 & 24.86 \\
\hline
\end{tabular}

Source: Statistical Year Book, Ministry of National Economy.

TABLE 4: Average monthly household food consumption by groups of commodities (O.R.) in the Sultanate of Oman.

\begin{tabular}{|c|c|c|c|c|}
\hline \multirow{2}{*}{ Groups of commodities } & \multicolumn{2}{|c|}{$1999-2000$} & \multicolumn{2}{|c|}{$2007-2008$} \\
\hline & O.R. & $\%$ & O.R. & $\%$ \\
\hline Cereals products & 18.10 & 13.07 & 17.54 & 12.31 \\
\hline Meat and poultry & 23.30 & 16.82 & 23.30 & 16.36 \\
\hline Fish & 7.80 & 5.63 & 9.34 & 6.55 \\
\hline Dairy and eggs & 15.00 & 10.83 & 14.80 & 10.39 \\
\hline Oil and fats & 3.40 & 2.45 & 3.06 & 2.15 \\
\hline Fruits & 14.70 & 10.61 & 12.12 & 8.51 \\
\hline Vegetables & 14.20 & 10.25 & 13.28 & 9.32 \\
\hline Sugar products & 5.10 & 3.68 & 5.07 & 3.56 \\
\hline Nonalcoholic beverages & 9.20 & 6.64 & 9.48 & 6.65 \\
\hline Food from restaurants & 12.40 & 8.95 & 22.02 & 15.46 \\
\hline Food from own production & 9.70 & 7.00 & 5.89 & 4.14 \\
\hline Others & 5.60 & 4.04 & 6.54 & 4.59 \\
\hline Total food consumption & 138.50 & 100 & 142.43 & 100 \\
\hline Total consumption & 456.04 & & 494.55 & \\
\hline Food as percentage of total consumptions & & 30.37 & & 28.80 \\
\hline
\end{tabular}

Source: main results of the Sultanate Expenditure and Income Survey for 1999-2000, Ministry of National Economy. Data for 2007-2008 are from nonpublished tables provided by the Ministry of National Economy.

income increases the share of food expenditure declines. In 2007-2008, the average household in Oman spent around 142.43 O.R. ${ }^{5}$. The main items in the food basket were meat and poultry, restaurants food, cereals, and dairy products which constitute, respectively, $16.4 \%, 15.5 \%, 12.3 \%$, and $10.4 \%$ of the total food consumption. Note the large increase in relative expenditure on food away from home (restaurant food) in $2008(15.46 \%)$ compared to $(8.95 \%)$ in 2000 . Relative consumption of food from own production has declined from $7 \%$ to $4.14 \%$ as well relative cereal consumption from $(13.1 \%$ to $12.3 \%$ ). These changes in the food consumption pattern in Oman are compatible with global trends as a result of income growth and urbanization.

Table 5 shows that in 2008 monthly rural household food consumption amounts to 154 Rials compared to 138.4 Rials for urban households. The proportion of total expenditure spent on food is much higher for rural households compared to urban households. This difference reflects the higher income and the higher access to nonfood consumption in the urban areas relative to rural areas. Again this is consistent with the Engel law, which states that poor households spend a higher proportion of their income on food. We should also notice that this proportion has declined over time for both rural and urban households. The comparison of the food basket composition in 2008 shows that rural households consume proportionally more cereals $(13.3 \%$ compared to $11.9 \%)$, more meat (17.3\% against $16 \%$ ), and more food from own production (14.2 against 3\%). On the other side we notice that urban households consume proportionally more dairy products (10.9\% against $9 \%$ ), more food away from home (17\% against $11.5 \%$ ), and slightly more beverage. Over time the food basket composition has not changed much except for "food from restaurants" category in which the proportion has increased substantially for both rural (from 4.6\% in 2000 to $11.5 \%$ in 2008 ) and urban households (from $10.5 \%$ in 2000 to $17 \%$ in 2008). We also notice that rural households 
TABLE 5: Monthly food consumption by commodity groups and locations.

\begin{tabular}{|c|c|c|c|c|c|c|c|c|}
\hline & \multicolumn{4}{|c|}{$1999-2000$} & \multicolumn{4}{|c|}{$2007-2008$} \\
\hline & \multicolumn{2}{|c|}{ Rural } & \multicolumn{2}{|c|}{ Urban } & \multicolumn{2}{|c|}{ Rural } & \multicolumn{2}{|c|}{ Urban } \\
\hline & O.R. & $\%$ & O.R. & $\%$ & O.R. & $\%$ & O.R. & $\%$ \\
\hline Cereals products & 19.8 & 13.4 & 17.5 & 13.0 & 20.5 & 13.3 & 16.5 & 11.9 \\
\hline Meat and poultry & 25.2 & 17.0 & 22.6 & 16.7 & 26.6 & 17.3 & 22.2 & 16.0 \\
\hline Fish & 8.5 & 5.8 & 7.6 & 5.6 & 9.8 & 6.4 & 9.2 & 6.6 \\
\hline Dairy and eggs & 12.2 & 8.2 & 16.0 & 11.8 & 13.8 & 9.0 & 15.1 & 10.9 \\
\hline Oil and fats & 3.4 & 2.3 & 3.4 & 2.5 & 3.1 & 2.0 & 3.1 & 2.2 \\
\hline Fruits & 15.4 & 10.4 & 14.5 & 10.7 & 13.0 & 8.5 & 11.8 & 8.5 \\
\hline Vegetables & 11.8 & 7.9 & 12.7 & 9.4 & 13.8 & 9.0 & 13.1 & 9.5 \\
\hline Sugar products & 5.7 & 3.8 & 4.9 & 3.6 & 5.3 & 3.4 & 5.0 & 3.6 \\
\hline Non-alcoholic beverages & 8.9 & 6.0 & 9.3 & 6.8 & 9.3 & 6.1 & 9.6 & 6.9 \\
\hline Food from restaurants & 6.8 & 4.6 & 14.2 & 10.5 & 17.7 & 11.5 & 23.5 & 17.0 \\
\hline Food from own production & 22.6 & 15.2 & 5.5 & 4.0 & 14.2 & 9.2 & 3.0 & 2.2 \\
\hline Others & 7.9 & 5.4 & 7.1 & 5.3 & 6.9 & 4.5 & 6.4 & 4.6 \\
\hline Total food consumption & 148.2 & 100 & 135.2 & 100 & 154.0 & 100 & 138.4 & 100 \\
\hline Total consumption & 361.1 & & 487.7 & & 402.7 & & 526.1 & \\
\hline Food as percentage of total consumptions & 41.0 & & 27.7 & & 38.2 & & 26.3 & \\
\hline
\end{tabular}

Source: main results of the Sultanate Expenditure and Income Survey for 1999-2000, Ministry of National Economy. Data for 2007-2008 are from non-published tables provided by the Ministry of National Economy.

TABle 6: Compensating variation due to the food price surge in 2006-2008.

\begin{tabular}{lcc}
\hline Household category & First-order effects (\%) & Full effects (\%) \\
\hline Oman & 9.91 & 10.3 \\
Locality & & \\
$\quad$ Urban & 9.27 & 9.77 \\
$\quad$ Rural & 11.73 & 12.45 \\
Income groups & & \\
$\quad$ 1st quartile & 11.32 & 11.54 \\
2nd quartile & 11.00 & 11.53 \\
3rd quartile & 10.59 & 10.15 \\
4th quartile & 9.91 & 9.69 \\
\hline
\end{tabular}

Source: Authors' own calculation. Note: Compensating variation is measured as a proportion of total household expenditure in 2006-2008.

depend for their food much more on the market than before as the proportion of food from "own production" declined substantially from $15.2 \%$ in 2000 to $9.2 \%$ in 2008 .

\section{Results and Discussion}

Equation (2) is used to assess the welfare consequences of the price changes during the food price crisis (20062008). Equation (2) permits to estimate the first round effect of the price increase (first term of (2)) as well as the second round effect, which considers household behavioral responses to the price changes (second term of the equation). The first round effect assumes that consumers do not change their consumption patterns in response to the price change (equivalent to assuming that all price elasticties are zero); this effect will depend only on the current budget shares and the level of price changes. The second effect is much more dynamic (as opposed to the static first round effect) where consumers substitute cheaper products for more expensive ones and accordingly change their consumption patterns.

We estimated the compensating variation for different population groups so as to recognize the differential impacts of the price change on these groups. Results are shown in Table 6. The figures represent the total transfer required to compensate households for the price changes they faced during the food crisis as a percentage of their initial total expenditure.

Table 3 shows the compensating variation for all households as well as for rural and urban households and 4 different income groups. Results suggested that all household groups suffered welfare losses due to the food crisis. On average, Omani households need to be compensated about $10.3 \%$ of their income for the price increase they experienced during the 2006-2008 period. The impact is felt differently by different household groups. Rural households are more affected than urban households as the compensation required amounts to around $12.45 \%$ compared to $9.77 \%$ for urban households. Note also that most of the impact is felt in the first round where no consumption adjustment is made; the second round effect is comparatively small to the first-order effect. The reason for this discrepancy is that little substitution occurred in consumption because the price increase has touched almost all commodities in the household basket. This result is quite different from those found in Ackah and Appleton [7] where the full effect is much smaller than the first-order effect in the particular setting of African countries. This can be explained by the fact that the analysis in Ackah and Appleton is concerned by the price changes during the 
1990s where actually the price of some commodities has increased while some others declined providing a room for substitution and a big change in consumption patterns.

Results by income quartile show that low-income household suffered slightly more from the food crisis than highincome groups, requiring targeted compensation policies that take into consideration these differential impacts.

Considering that the average monthly household consumption expenditure is around 495 Omani Rials (O.R.) and the number of households in Oman is 449639 (The Ministry of National Economy, 2012) the total annual amount of the compensation needed to compensate all households amounts to 266.6 Million Omani Rials. This figure represents 1.14\% of the GDP which is still in the low range of subsidy figures that countries in the Middle East and North African region (MENA) have spent on food during the food crisis period. For example, in 2008, food subsidies ranged between $0.8 \%$ of GDP in Morocco, $1.8 \%$ in Egypt, $2.1 \%$ in Tunisia, $2.8 \%$ in Syria, and 3.5\% in Iraq [2].

A targeted compensation strategy would however provide compensation mainly for those households who are in the low-income bracket. According to the household expenditure and income survey, monthly household 1 expenditure of the 1st quartile amounts to O.R. 175 Omani Rials [16] and, given our estimate of the needed compensation for this quartile (11.3\%), the total annual compensation required amounts to O.R. 26.65 Million which represents only $0.1 \%$ of GDP.

\section{Conclusion}

The objective of the paper was to evaluate the impact of high food prices during the 2006-2008 food crisis period on the welfare of households in the Sultanate of Oman. The paper used a partial equilibrium approach to trace out the effects of price changes, through the estimation of Hicksian compensating variation. Results suggested that all household groups suffered welfare losses due to the food crisis. On average, Omani households need to be compensated about $10.3 \%$ of their income for the price increase they experienced during the 2006-2008 period. Rural households are more affected than urban households, requiring a compensation of $12.45 \%$ compared to $9.77 \%$ for urban households. In addition low-income groups are more affected than highincome groups, requiring targeted compensation policies.

The total compensation required to compensate all households amounts to O.R. 266.6 M representing about $1.14 \%$ of GDP. However if only the low income quartile receives compensation, the targeted transfer amounts to O.R. 26.65 $\mathrm{M}$ representing $0.1 \%$ of GDP. Despite the lack of data to estimate compensation for more refined income groups, the method presented in this paper as well as the results can serve as a basis for the Omani government to design food safety net policies that compensate consumers according to their welfare loss during food crisis periods.

The study has been limited to the consumption side ignoring the supply side adjustments to price changes, including household income as well as the price-wage relationship. Some food producers may have gained from the price increase but food production in Oman constitutes a small proportion of total consumption and therefore any gain incurred from the price increase would be limited. These aspects are left for further research. In addition, this paper did not tackle the issue of the impact of rising food prices on poverty. Absolute poverty in Oman is not widespread and income distribution has improved significantly during the last decade (Gini coefficient changed from 46.49 to 36.35 from 2000 to 2008). Absolute poverty defined as the lack of access to a least-cost diet has been estimated in a separate study $^{6}$ to be around $8.6 \%$ in 2008 compared to $6.4 \%$ in 2006 , a change due to the price hike during that period. Further analysis however is needed at the household level to explore this issue in more details using more refined indictors other than head counts.

\section{Conflict of Interests}

The authors declare that there is no conflict of interests regarding the publication of this paper.

\section{Acknowledgment}

The authors would like to acknowledge Sultan Qaboos University for funding this research project.

\section{Endnotes}

1. The Public Authority for Stores and Food Reserves is a government entity, created in 1980, responsible for managing public food warehouses and stabilizing food prices. Price stabilization is reached through maintaining a minimum food reserve for basic food commodities (rice, wheat, sugar, cooking oil, lentils, and dried milk) and a nationwide distribution network of agent stores that sell the products at cost or fixed prices.

2. The estimated augmented share equation has the following form:

$$
w_{i h}=\alpha_{i}+\beta_{i} \log \left(x_{h}\right)+\sum_{j=1}^{l} \delta_{j} Z_{j h}
$$

where $w_{i h}$ is the budget share of the $i$ th good and household $h, x_{h}$ is the total food expenditure of household $h$, and $Z_{j h}$ is a vector of household sociodemographic characteristics. The household characteristics included in the model are the household size, the age of the household head, and a number of dummies reflecting the nationality, the residence region, the gender, and whether the household lives in the urban or the rural area.

3. The parameters and elasticity estimates of the Engel share equations are not presented in this paper but are available from the authors on request.

4. The primary data for more recent surveys are not available for the public. Only summary tables are made available to the researchers. 
5. The Omani Rial is pegged to the dollars and 1 Omani Rial $=2.6$ US dollars.

6. Al-Jabri Salwa. Economic Analysis of Household Food Security. Unpublished Master Thesis. Sultan Qaboos University, 2012.

\section{References}

[1] World Bank, "Rising food prices: policy options and World Bank responses," 2008, http://siteresources.worldbank.org/ NEWS/Resources/risingfoodprices_backgroundnote_apr08. pdf.

[2] R. Alber and M. Peeters, "Food and energy prices, government subsidies and fiscal balances in the South Mediterranean countries," Economic Papers 437, European Commission, Brussels, Belgium, 2011.

[3] L. Tuck and K. Lindert, "Form universal subsidies to targeted subsidies: a case study in Tunisia reforms," World Bank Discussion Paper 351, The World Bank, Washington, DC, USA, 1996.

[4] D. Coady, "Designing and evaluating social safety nets: theory, evidence, and policy conclusions," 2004, http://www.ifpri.cgiar. org/sites/default/files/publications/fcndp172.pdf.

[5] "Oman Daily Observer: subsidies on food item continues," 2011, http://main.omanobserver.om/node/75281 .

[6] A. Deaton and J. Muellbauer, Economics and Consumer Behavior, Cambridge University Press, New York, NY, USA, 1980.

[7] C. Ackah and S. Appleton, "Food price changes and consumer welfare in Ghana in the 1990's," 2007, http://www.nottingham.ac .uk/credit/index.aspx.

[8] M. Ivanic and W. Martin, "Implications of higher global food prices for poverty in low-income countries," Agricultural Economics, vol. 39, supplement 1, pp. 405-416, 2008.

[9] S. Dessus, S. Herrera, and R. de Hoyos, "The impact of food inflation on urban poverty and its monetary cost: some backof-the-envelope calculations," Agricultural Economics, vol. 39, supplement 1, pp. 417-429, 2008.

[10] J. Friedman and J. Levinsohn, "The distributional impacts of Indonesia's financial crisis on household welfare: a rapid response methodology," World Bank Economic Review, vol. 16, no. 3, pp. 397-423, 2002.

[11] J. M. Alston, C. A. Carter, R. Green, and D. Pick, "Whither Armington trade models?" American Journal of Agricultural Economics, vol. 72, no. 2, pp. 455-467, 1990.

[12] A. Deaton, "Rice prices and income distribution in Thailand: a non-parametric analysis," Economic Journal, vol. 99, no. supplement 395, pp. 1-37, 1989.

[13] A. Omezzine, H. Boughanmi, and H. Al Oufi, "Demand elasticities of fresh fish commodities in Oman," Journal for Scientific Research-Agricultural Sciences, vol. 8, no. 2, pp. 5561, 2003.

[14] J. Seale, A. Regmi, and J. Bernstein, "International evidence on food consumption patterns," 2003, http://www.ers.usda. gov/data.

[15] A. Regmi and J. Seale, "Cross price elasticties of demand across 114 countries,” 2010, http://www.ers.usda.gov/data .

[16] Ministry of national Economy, "Household expenditure and income survey," Oman, 2010. 

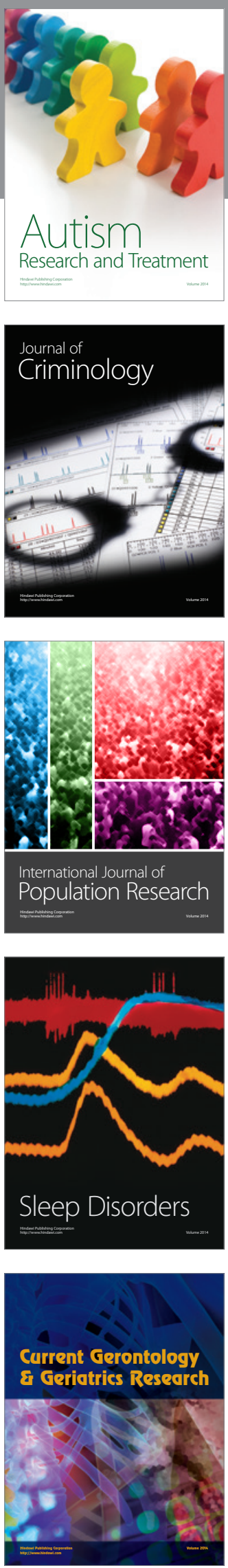
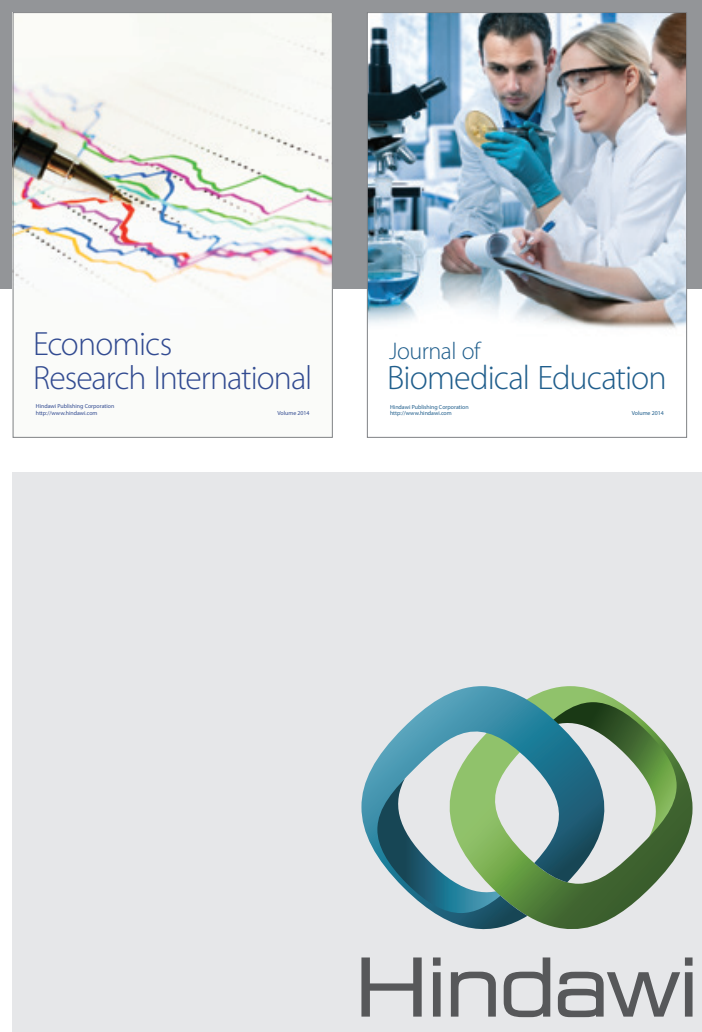

Submit your manuscripts at

http://www.hindawi.com
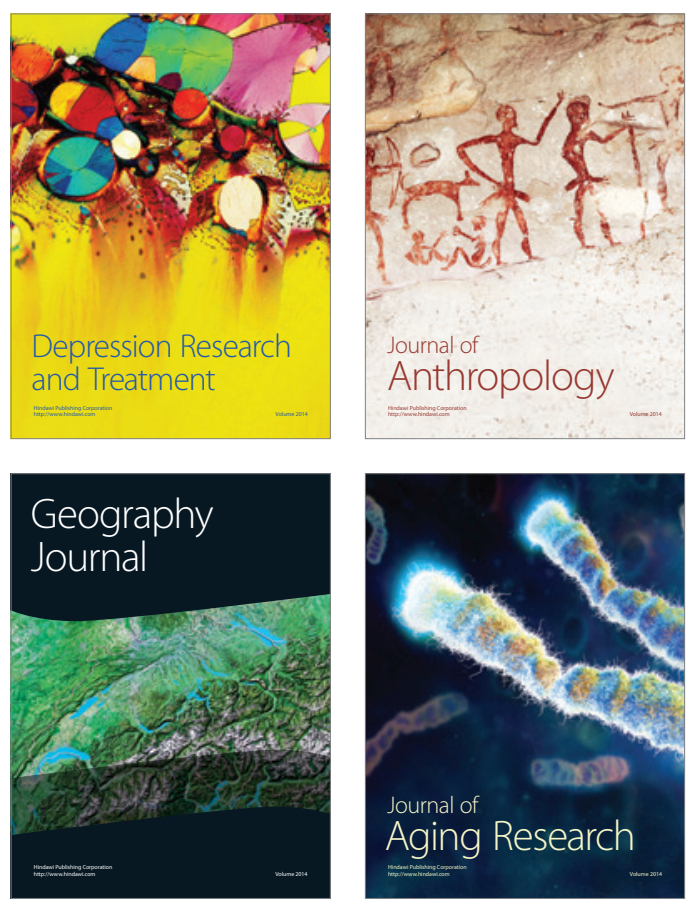
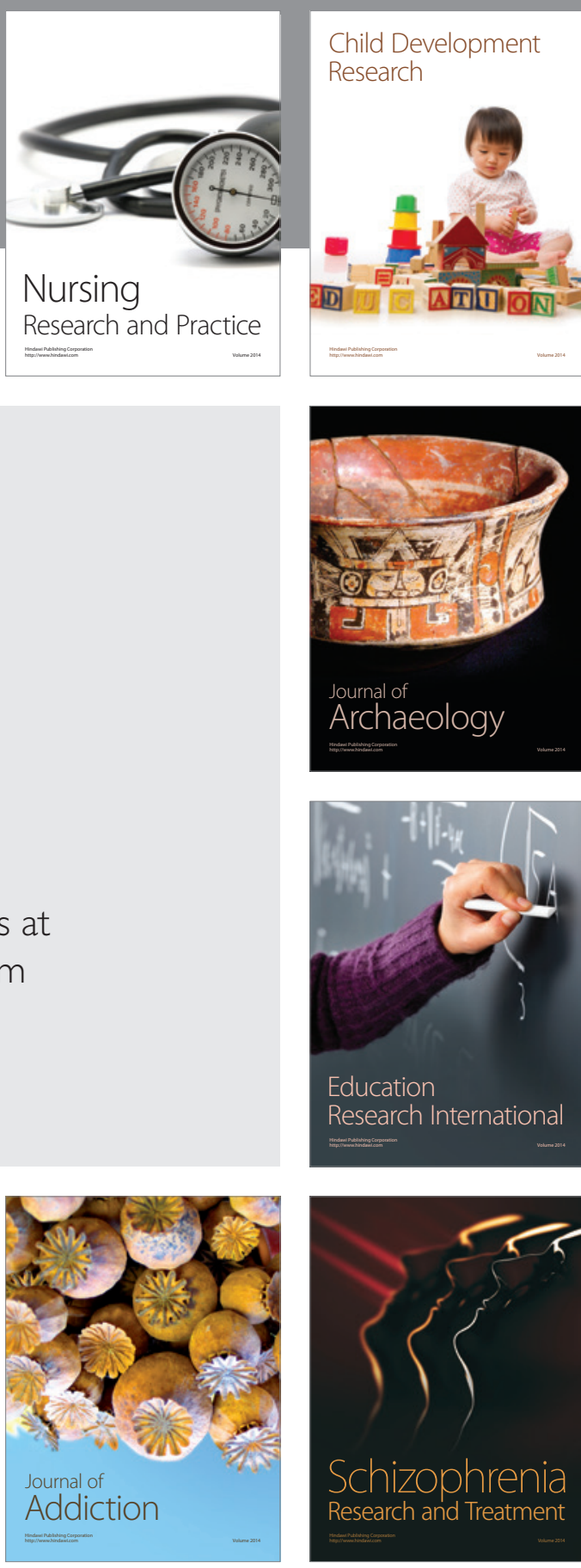

(D)
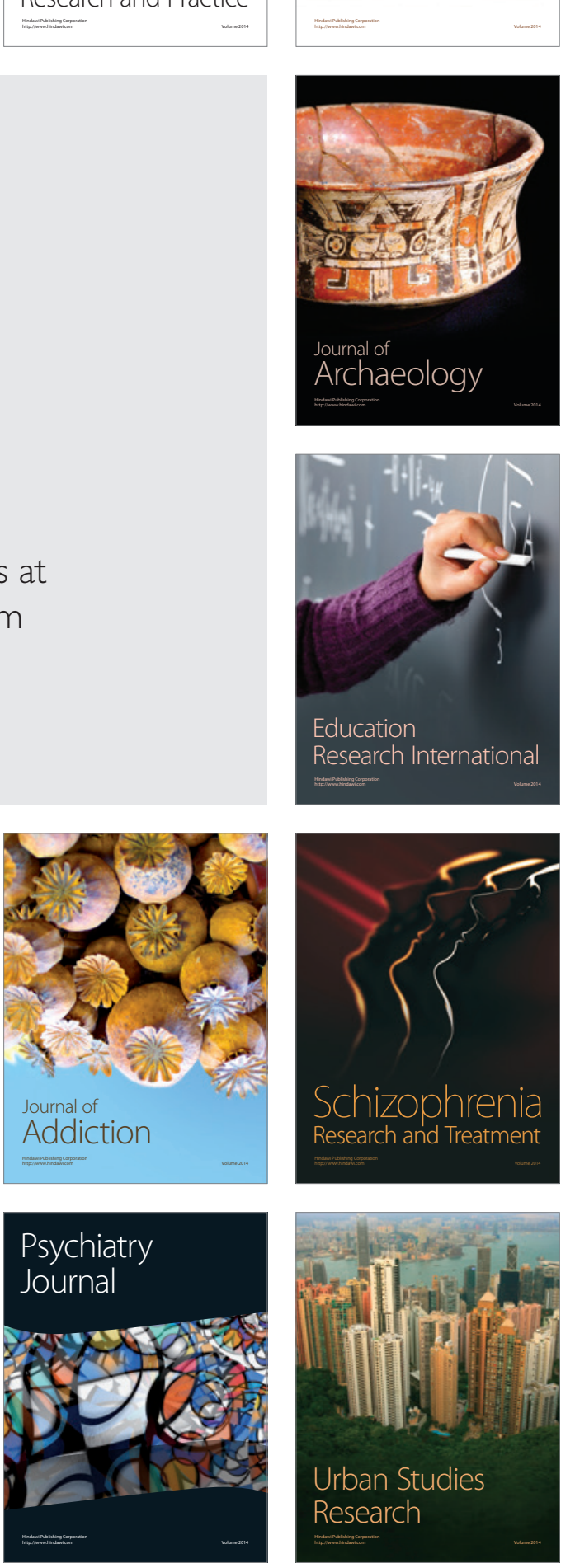